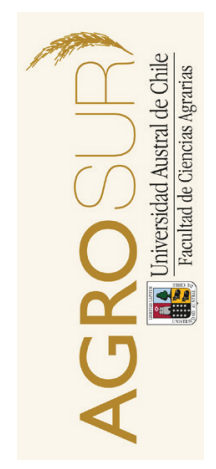

\title{
Cambios en los contenidos de metales pesados (arsénico, cadmio y mercurio) en productos pesqueros durante los procesos de cocción
}

\author{
Changes in heavy metals (arsenic, cadmium and mercury) \\ contents in seafoods during cooking processes
}

\author{
Muñoz, O. ${ }^{a}$, Cid, H. ${ }^{a}$, Ah-Hen, K. ${ }^{a *}$, Bastías, J.M. ${ }^{b}$ \\ ${ }^{a}$ Instituto de Ciencia y Tecnología de los Alimentos, Facultad de Ciencias Agrarias, \\ Universidad Austral de Chile, Av. Julio Sarrazín s/n, Campus Isla Teja, Valdivia, Chile. \\ b Departmento de Ingeniería en Alimentos, Universidad del Bío-Bío, Av. Andrés Bello s/n, Chillan, Chile.
}

\begin{tabular}{|c|c|}
\hline RT I C LE INF O & $\mathrm{CT}$ \\
\hline Keywords: & \multirow{9}{*}{$\begin{array}{l}\text { The aim of this study was to determine the effect of cooking on changes in arsenic, cadmium, and } \\
\text { mercury concentrations in boiled and baked seafoods. Fish, like Jack mackerel (Trachurus murphyi } \\
\text { Nichols, 1920) and black cusk-eel (Genypterus maculatus Tschudi, 1846), and shellfish, like clam } \\
\text { (Prototha cathaca Molina, 1782), common mussel (Mytilus chilensis Hupé 1854) and Magellan } \\
\text { mussel (Aulacomya atra Molina, 1782) were selected for the study. Both cooking processes caused a } \\
\text { significant reduction in the arsenic content found in three of the fresh samples; in common mussel } \\
\text { and black cusk-eel, arsenic concentrations showed no significant changes (p < 0.05). Similarly, } \\
\text { cadmium content was also reduced in three of the five analysed seafoods, with common mussels } \\
\text { and clam showing no significant changes in cadmium contents. In terms of mercury concentration } \\
\text { no statistically significant difference between fresh and cooked fish samples was observed, which } \\
\text { showed that mercury is a particular health risk due to the formation of methylmercury that is not } \\
\text { solubilised during cooking. It was found that the cooking processes, such as baking and boiling, do } \\
\text { have a significant effect on the heavy metal content of seafoods, but the extent of the reduction would } \\
\text { depend on the particular seafood and heavy metal analysed. }\end{array}$} \\
\hline Arsenic & \\
\hline Cadmium & \\
\hline Mercury & \\
\hline Heavy metals & \\
\hline Seafoods & \\
\hline Cooking process & \\
\hline $\begin{array}{l}\text { Original Research Article, } \\
\text { Food Science }\end{array}$ & \\
\hline $\begin{array}{l}\text { *Corresponding author: } \\
\text { Kong Ah-hen } \\
\text { E-mail address: } \\
\text { kshun@uach.cl }\end{array}$ & \\
\hline
\end{tabular}

RESUMEN

El propósito de este estudio fue determinar los efectos de los procesos de cocción sobre los contenidos de arsénico, cadmio y mercurio en algunos productos pesqueros hervidos y horneados. Pescados, como jurel (Trachurus murphyi Nichols, 1920) y congrio negro (Genypterus maculatus Tschudi, 1846), además de mariscos, como almeja (Prototha cathaca Molina, 1782), chorito común (Mytilus chilensis Hupé 1854) y cholga (Aulacomya atra Molina, 1782) fueron elegidos para el estudio. Se observó que ambos procesos de cocción tuvieron una reducción significativa en la concentración de arsénico en tres de las cinco muestras frescas; en el chorito común y el congrio negro, la concentración de arsénico no varió significativamente $(\mathrm{p}<0,05)$. De forma similar, hubo también una reducción del contenido de cadmio en tres de las cinco muestras analizadas y la variación de concentración de cadmio no era significativa en el chorito común y en la almeja. En cuanto al mercurio, se observó que no hubo diferencias significativas de concentraciones entre los productos frescos y cocidos, lo que indicó un riesgo particular a la salud humana, debido a la formación del metil mercurio que no se solubiliza durante la cocción. Se encontró que tanto el proceso de horneado como de hervido tiene un efecto significativo sobre el contenido de metales pesados en los productos pesqueros, sin embargo, la magnitud de la reducción dependerá del producto y del metal pesado analizado.

Palabras clave: Arsénico, Cadmio, Mercurio, metales pesados, productos del mar, proceso de cocción.

\section{INTRODUCTION}

Ingestion of heavy metals by humans occurs mainly through consumption of contaminated food. However, as reported in several comprehensive dietary studies, seafood may be an important source of arsenic, cadmium and mercury, to which human beings are exposed (Llobet et al., 2003; Muñoz et al., 2005; Olmedo et al., 2013). Despite the potential health benefits of dietary fish intake, the chemical polluants of heavy metals in these products have emerged as an issue of concern, especially for frequent fish consumers (Martorell et al., 2011). Arsenic in its different chemical forms can be found in high concentrations in seafood (Shiomi, 1994; Olmedo et al., 2013; Chahid et al., 2014). These compounds differ in their degree of toxicity and in the pathologies they generate. Consumption of arsenic generally leads to many forms of cardiovascular, dermatological, hematological, hepatic, and renal illnesses. Arsenic may also cause cancer of the genitals, the urinary tract, the respiratory system and the skin (Olmedo et al., 2013). 
Cadmium is found in very high concentrations in fish, shellfish and cereals (Llobet et al., 2003) and its presence in food has been considered one of the most significant risk factor for long-term effect on the human body, since it tends to accumulate in human tissues. Cadmium has an estimated biologic half-life of 20-30 years and the bodily cadmium load of a person reaches typically a plateau at around the age of 50 years. Almost half of the body's cadmium load is concentrated in the liver and kidneys. The kidney is generally regarded as the most vulnerable organ prone to chronic cadmium poisoning (Manahan, 2003). Cadmium is also known to be carcinogenic and may cause lung tumors and possibly prostate cancer (Manahan, 2003). The most spectacular and publicised instance of cadmium poisoning occurred, when the people in the Jintsu River Valley, near Fuchu, Japan, ingested rice contaminated with toxic levels of cadmium. The victims were afflicted with the itai-itai disease, which in Japanese tongue means "it hurts-it hurts". The symptoms of the disease include painful bone disease (osteomalacia) and kidney malfunction (Horiguchi et al., 2006).

Mercury occurs naturally in different forms at different concentrations (ATSDR, 1999). All forms of mercury are toxic to living organisms. The inorganic form of mercury is biologically transformed in aquatic environments into methyl mercury (MeHg), a lipophilic organic compound that bioaccumulates and biomagnifies, as it moves up the aquatic food chain (Carrasco et al., 2011). MeHg ingested by human beings through the diet is completely absorbed in the gastrointestinal tract and distributed to most tissues (ATSDR, 2003). Poisoning by $\mathrm{MeHg}$ can produce alterations in the intestinal mucosa, general enzymatic inhibition, teratogenic effects, genetic alterations and kidney damage (ATSDR, 2003). MeHg can cross the placental barrier to reach the fetal bloodstream, where it primarily builds up in nervous tissues, causing ultimately mental retardation among other negative health effects in newborn children (ATSDR, 1999; Jin et al., 2013). The most spectacular and publicised instance of mercury poisoning occurred in Kumamoto, Japan, where an epidemic neurological disorder, known as Minamata disease, broke out when people in that region consumed fish contaminated with high levels of MeHg. The poisoning was traced back to the consumption of methyl mercury chloride $\left(\mathrm{CH}_{3} \mathrm{HgCl}\right)$, which was generated as a by-product in an acetaldehyde plant in Minamata and subsequently discharged into the Minamata Bay and River. Consumption of the contaminated fishes and shellfishes caused more than 2000 confirmed cases of Minamata disease and more than 10,000 suspected cases until 1996 (Ekino et al., 2004).

In the present work, a selection of frequently consumed fishes and bivalves were subjected to culinary processing, such as boiling and baking, to determine the effect of heat treatment on arsenic, cadmium, and mercury contents in the seafoods and to find out, if there is any significant change in the toxicological risk, owing to consumption of the cooked seafood products.

\section{MATERIALS AND METHODS}

\section{Laboratory material treatment and reagents}

All glass and plastic materials used were carefully washed, treated with $10 \%(\mathrm{v} / \mathrm{v})$ nitric acid for 24 hours, rinsed in reaction grade $\left(18 \mathrm{M} \Omega \mathrm{cm}^{-1}\right)$ deionised water, and air dried. Elaborated washing procedures were necessary and were performed in order to remove any contaminating substances that may possibly interfere with the study.

All reagents used were of analytical grade. Deionised water $\left(18 \mathrm{M} \Omega \mathrm{cm}^{-1}\right)$ was used to prepare any reagent solutions.

\section{Sample preparation}

Two types of fish, Jack mackerel (T. murphyi) and black cusk-eel (G. maculatus) and three types of bivalves, clam (P. cathaca), common mussel (M. chilensis) and Magellan mussel (A. myaater), were analysed. Five samples of each species were obtained from public sales points in Santiago, Chile and immediately taken to the laboratory for analysis. The samples were washed with deionised water $\left(18 \mathrm{M} \Omega \mathrm{cm}^{-1}\right)$, and divided roughly into three equal portions ( $250 \mathrm{~g}$ ), one for each experimental treatment (fresh, boiled and baked). For analysis of the fresh samples, excess water was first drained off. Samples were then homogenised in a household food processor, and stored in low-density polyethylene containers at $-18{ }^{\circ} \mathrm{C}$ until analysis. For analysis of the cooked products, samples were subjected to boiling or baking. Neither salt nor spices were added, in order to avoid any potential modification of the metal content in the samples. Following thermal treatment, the samples were drained to remove excess water, homogenised, and stored at $-18^{\circ} \mathrm{C}$ until analysis.

\section{Cooking processes - boiling and baking}

Boiling was performed in a stainless steel pot in 500 $\mathrm{mL}$ deionised water (18 $\left.\mathrm{M} \Omega \mathrm{cm}^{-1}\right)$ that was brought to the boil, before adding the seafood sample ( $250 \mathrm{~g}$ ). After 10 minutes, the sample was removed with a slotted spoon. Bivalves were boiled in their shells.

Baking was performed in an oven (Fensa 2265, Santiago, Chile) pre-heated to $250{ }^{\circ} \mathrm{C}$ for $15 \mathrm{~min}$. Sample was placed in a Pyrex glass pan and total cooking time was adjusted to seafood products. Bivalves were baked in their shells for $40 \mathrm{~min}$, black cusk-eels for $100 \mathrm{~min}$ and Jack mackerel for 70 min. 


\section{Determination of heavy metals}

To avoid any distortion of the heavy metals concentrations based on the differences in moisture content between samples, all concentrations were based on dry weight $(\mathrm{dw})$ of sample.

\section{Total arsenic and cadmium contents}

The seafood samples were thawed and homogenised. Samples of $2.00 \pm 0.01 \mathrm{~g}$ were weighed accurately in 100 $\mathrm{mL}$ tall form borosilicate glass beakers. To each sample, $5 \mathrm{~mL}$ of deionised water, $20 \mathrm{~mL}$ concentrated $\mathrm{HNO}_{3}$ and $1 \mathrm{~mL} 7.4 \%(\mathrm{w} / \mathrm{v})$ magnesium oxide mineralisation agent were added. The samples were slowly heated on a hotplate. When volume of mixture reached approximately $10 \mathrm{~mL}, 5 \mathrm{~mL}$ of $30 \%$ (v/v) $\mathrm{H}_{2} \mathrm{O}_{2}$ were added. The samples were then evaporated to dryness. The dried samples were then incinerated to mineral ash in an oven at $400 \stackrel{\circ}{\circ} \mathrm{C}$ for $12 \mathrm{~h}$. If any carbonised organic matter remained after incineration, $5 \mathrm{~mL}$ of $50 \%(\mathrm{v} / \mathrm{v}) \mathrm{HNO}_{3}$ was added before repeating the hotplate and incineration treatments, as described. The completely mineralised sample was hydrated with $1 \mathrm{~mL}$ water and $1 \mathrm{~mL}$ concentrated $\mathrm{HCl}$. Mixture was shaken gently and left to dissolve for 1 hour. Once the samples were dissolved, they were filtered into a $25 \mathrm{~mL}$ flat-bottomed flask using Whatman No. 1 filter paper. The filter residue was first washed with $2 \mathrm{~mL} 50 \%$ $(\mathrm{v} / \mathrm{v}) \mathrm{HCl}$ and then several times with $1 \%(\mathrm{v} / \mathrm{v}) \mathrm{HNO}_{3}$ until the total volume of $25 \mathrm{~mL}$ was reached. From this solution, a $1 \mathrm{~mL}$ aliquot was removed to determine total arsenic content (total As). The remaining $24 \mathrm{~mL}$ were used to determine cadmium content (Cd).

To determine total arsenic content $5 \mathrm{~mL}$ of $50 \%$ $(\mathrm{v} / \mathrm{v}) \mathrm{HCl}$ and $5 \mathrm{~mL}$ of a mixture of $5 \%(\mathrm{w} / \mathrm{v}) \mathrm{KI}$ and $5 \%(\mathrm{w} / \mathrm{v})$ ascorbic acid were added to the $1 \mathrm{~mL}$ aliquot and left for 30 minutes to equilibrate. To the solution $25 \mathrm{~mL}$ of $50 \%(\mathrm{v} / \mathrm{v}) \mathrm{HCl}$ were added and total As was measured via Hydride Generation by Atomic Absorption Spectrometry (HG-AAS), using a Varian Spectra A-55 instrument. Cadmium content was determined by Flame Atomic Absorption Spectrophotometry (F-AAS). The analytical parameters for both determinations are summarised in Table 1.

\section{Inorganic arsenic content}

Inorganic arsenic content was determined by the method described by Muñoz et al. (1999a). In brief, $0.50 \pm 0.01 \mathrm{~g}$ of dried sample was placed in a $50 \mathrm{~mL}$ centrifuge tube with a screw top. A volume of $4.1 \mathrm{~mL}$ water was added, and the sample was shaken to complete humectation. Then, $18.4 \mathrm{~mL}$ of concentrated $\mathrm{HCl}$ was added, and the mixture was shaken for 2 hours and left overnight to equilibrate (12-15 hours). $2 \mathrm{~mL} \mathrm{HBr}$ and $1 \mathrm{~mL} 1.5 \%(\mathrm{w} / \mathrm{v})$ sulphate hydracynium as redu-
Table 1. Instrumental parameters for determination of total As, inorganic As, Cd and $\mathrm{Hg}$.

Cuadro 1. Parámetros instrumentales en la determinación de As total, As inorgánico, $\mathrm{Cd}$ y Hg.

\begin{tabular}{|c|c|}
\hline & Parameters \\
\hline \multicolumn{2}{|l|}{ Arsenic } \\
\hline Sample flow & $5.0\left[\mathrm{ml} \mathrm{min}^{-1}\right]$ \\
\hline Reduction Solution & $\begin{array}{l}\mathrm{NaBH}_{4} 1.5 \%[\mathrm{w} / \mathrm{v}] ; \mathrm{NaOH} \text { at } 0.7 \% \\
{[\mathrm{w} / \mathrm{v}], \text { flow of } 5.0\left[\mathrm{ml} \mathrm{min}^{-1}\right]}\end{array}$ \\
\hline Carrier Gas & Nitrogen $99 \%$ \\
\hline Wavelength & $193.7 \mathrm{~nm}$ \\
\hline Cell Temperature & $900^{\circ} \mathrm{C}$ \\
\hline \multicolumn{2}{|l|}{ Cadmium } \\
\hline Wavelength & $228.8 \mathrm{~nm}$ \\
\hline \multicolumn{2}{|l|}{ Mercury } \\
\hline Sample flow & $4.5-5.5\left[\mathrm{ml} \mathrm{min}^{-1}\right]$ \\
\hline Reduction Solution & $\begin{array}{l}\mathrm{SnCl}_{2} 2.0 \%[\mathrm{w} / \mathrm{v}] \text { in } \mathrm{HCl} \text { at } 15 \% \\
{[\mathrm{w} / \mathrm{v}], \text { flow of } 4-5[\mathrm{ml} / \mathrm{min}]}\end{array}$ \\
\hline Carrier Gas & Nitrogen $99 \%$ \\
\hline Wavelength & $253.7 \mathrm{~nm}$ \\
\hline Cell Temperature & $900^{\circ} \mathrm{C}$ \\
\hline
\end{tabular}

cing agent were added to the equilibrated solution, and the mixture was shaken for $30 \mathrm{~s}$. Subsequently, $10 \mathrm{~mL}$ of chloroform $\left(\mathrm{CHCl}_{3}\right)$ was added, and the mixture was shaken again for $3 \mathrm{~min}$. The aqueous and organic phases were separated by centrifugation at $2000 \mathrm{rpm}$ for $5 \mathrm{~min}$. The organic phase was removed by aspiration and kept in another tube. The chloroform extraction process was repeated two more times. The combined organic phases were centrifuged once more. The aqueous remnants left in the organic phase were removed by aspiration, and the organic phase was filtered through Whatman No. 1 filter paper. The organic phase was combined to $10 \mathrm{~mL}$ of $1 \mathrm{~N} \mathrm{HCl}$ and back-extracted by shaking for $3 \mathrm{~min}$. The phases were separated once again by centrifugation at $2000 \mathrm{rpm}$ for $5 \mathrm{~min}$ and the aqueous phase was aspirated and kept in a tall form borosilicate glass beaker. Back extraction was repeated, and the aqueous phases were combined. To determine concentration of inorganic arsenic in the aqueous phase, $2.5 \mathrm{~mL}$ of the mineralization agent $(7.4 \% \mathrm{w} / \mathrm{v} \mathrm{MgO})$ and $10 \mathrm{~mL}$ of concentrated $\mathrm{HNO}_{3}$ were added. The solution was then dried on a hotplate and employed in the same manner as for the measurement of total arsenic. 


\section{Mercury content}

Samples were thawed and homogenised and 1.00 $\pm 0.01 \mathrm{~g}$ of sample was accurately weighed and placed in a tall form borosilicate glass beaker. $10 \mathrm{~mL}$ of concentrated $\mathrm{HNO}_{3}$ was then added, and the sample was digested at a moderate temperature for $30 \mathrm{~min}$. The sample was cooled and $5 \mathrm{~mL} 30 \% \mathrm{v} / \mathrm{v}_{2} \mathrm{O}_{2}$ were added and digestion continued until total volume of mixture was reduced to $5 \mathrm{~mL}$. Aliquots of $\mathrm{HNO}_{3}$ and $\mathrm{H}_{2} \mathrm{O}_{2}$ were added as necessary, and digestion continued until the solution was completely clear. The digested solution was left to equilibrate for 12 hours to eliminate nitrous vapours. The equilibrated solution was then filtered through Whatman No. 1 filter paper and diluted with $5 \% \mathrm{v} / \mathrm{v} \mathrm{HCl}$ to a final volume of $25 \mathrm{~mL}$. Mercury concentration was measured via Cold Vapour Atomic Absorption Spectroscopy (CV-AAS); the analytic conditions employed are summarised in Table 1.

\section{Validation of the analytical methods}

In order to assure the reliability of the results, assays were performed to determine the limit of detection (LOD), accuracy, and precision of methods for analysis of As, Cd and Hg. LOD was obtained using nine reagent blanks. Accuracy of methods was expressed as the percentage recovery (\% Recovery) of mean value from three independent analyses, while precision of method was given as relative standard deviation (\% RSD) for six independent analyses. Results are summarised in Table 2.

\section{Statistical Analysis}

To compare the total arsenic, inorganic arsenic, cadmium, and mercury contents (mean \pm standard deviation) in the various types of seafood, the heavy metal concentrations (based on dry weight of seafood sample) were analysed using an unbalanced repeated-measure ANOVA model and Tukey comparisons between means for each type of seafood. The statistical analysis was performed using Statgraphics Plus 5.1 software.

\section{RESULTS AND DISCUSSION}

\section{Total arsenic content in fresh and cooked seafood samples}

The average concentrations of total arsenic (total As) present in the fresh and cooked seafood samples are shown in Table 3. Among the analysed bivalves, the Magellan mussels had the highest total As concentration (13.3-14.7 $\left.\mu \mathrm{g} \mathrm{g}^{-1} \mathrm{dw}\right)$, followed by clams $(8.9-13.1$ $\mu \mathrm{g} \mathrm{g}^{-1} \mathrm{dw}$ ) and common mussels (6.18-8.36 $\left.\mu \mathrm{g} \mathrm{g}^{-1} \mathrm{dw}\right)$. The values observed in the present study were within the normal limits (4.38-26.11 $\left.\mu \mathrm{g} \mathrm{g}^{-1} \mathrm{dw}\right)$, as defined in literature for similar species (Vlieg et al., 1991; Larsen et al., 1993; López et al., 1994; Schuhmacher and Domingo 1996; Šlejkovec et al., 1996; Muñoz et al., 2000). Between the two tested fish species, the black cusk-eel had higher concentration of total As (3.6 - $4.6 \mu \mathrm{g} \mathrm{g}^{-1} \mathrm{dw}$ ) compared to Jack mackerel $\left(1.7-2.8 \mu \mathrm{g} \mathrm{g}^{-1} \mathrm{dw}\right)$ that is within the range of total As ( $\left.0.5-14.57 \mu \mathrm{g} \mathrm{g}^{-1} \mathrm{dw}\right)$ reported in literature for such fish (Brooke and Evans 1981; Vlieg et al., 1991; Attar et al., 1992; Leah et al., 1992; Larsen et al., 1993; Branch et al., 1994; López et al., 1994; Ackley et al., 1999; Muñoz et al., 2000).

The average concentrations of total As in both baked and boiled samples of three of the tested products (clam, Magellan mussel and Jack mackerel) showed a statistically significant decrease during both culinary processes. In the case of common mussel and black cusk-eel, no significant differences were observed in concentration of total As in samples subjected to the thermal treatments. The significant difference in total As may be attributed to sample dehydration during cooking, since significant quantities of As can be exuded together with liquid from the samples. Possible volatilisation of As under normal cooking conditions has not been confirmed. However, several studies have reported that cooking increased the solubility of organoarsenical species (Devesa et al., 2001). Solubilisation may be due to lability of the electrostatic bond between arseno-betaine $(\mathrm{AB})$ and the fish muscle proteins. Solubilisation of two arsenic species, $A B$ and dimethyl arsenic acid (DMA), was also demonstrated in a study

Table 2. Analytical characteristics of methods for determination of arsenic (HG-AAS), cadmium (F-AAS) and mercury (CV-AAS). Cuadro 2. Característicos analíticos de los métodos de determinación de arsénico (HG-AAS), cadmio (F-AAS) y mercurio (CV-AAS)

\begin{tabular}{lcccc}
\hline & Arsenic & cadmium & Mercury \\
\hline Limit of Detection (LoD) $\left(\mu \mathrm{g} \mathrm{g}^{-1}\right)$ & ${ }^{\mathrm{a}} 0.011$ & ${ }^{\mathrm{b}} 0.003$ & 0.095 & 0.010 \\
Precision (RSD \%) & ${ }^{\mathrm{a}} 2.8$ & ${ }^{\mathrm{b}} 5.8$ & 2.1 & 7.2 \\
Accuracy (Recovery \%) & ${ }^{\mathrm{a}} 102.4$ & ${ }^{\mathrm{b}} 87$ & 94.2 & 96.8 \\
\hline
\end{tabular}

${ }^{\mathrm{a}}$ Total As, ${ }^{\mathrm{b}}$ Inorganic As. 
in which the liquid accompanying canned fish was examined (Vélez et al., 1997). In vegetables, a reduction in arsenic levels following cooking was also demonstrated (Low and Lee, 1992), but there was no indication as to whether this reduction was due to volatilisation or solubilisation of arsenic. Devesa et al. (2001) studied the presence of organo-arsenical species in the cooking liquids from baked and with deionised water steamed samples of crustaceans and bivalves, and confirmed that the observed reduction in As content following cooking was due to solubilisation. Arsenic was detected in all of the accompanying liquids. Experiments to identify the exact arsenic species present in these liquids, using HPLC-microwave-assisted oxidation-HGAAS in accordance to the methodology of Vélez et al. (1997), indicated the presence of $A B$ in cooking liquids from crustaceans. Both $\mathrm{AB}$ and small quantities of DMA were found in cooking liquid from bivalves.

\section{Inorganic arsenic content in fresh and cooked seafood samples}

The concentrations of inorganic As in the tested species are presented in Table 3. The fresh bivalves possessed the highest content of inorganic As. Common mussels had values in the range of $0.181-0.227 \mu \mathrm{g} \mathrm{g}^{-1} \mathrm{dw}$, followed by Magellan mussels, with values within $0.125-0.168 \mu \mathrm{g} \mathrm{g}^{-1} \mathrm{dw}$, and clams with values within $0.108-0.182 \mu \mathrm{g} \mathrm{g}^{-1} \mathrm{dw}$. Similar values $(0.140-1.588 \mu \mathrm{g}$ $\mathrm{g}^{-1} \mathrm{dw}$ ) as those found in the tested bivalves have been reported in literature (Larsen et al., 1993; López et al., 1994; Šlejkovec et al., 1996; Muñoz et al., 1999a; Muñoz et al., 1999b; Muñoz et al., 2000). Between the two fresh fish species tested, the higher concentrations of inorganic As were observed in the black cusk-eel (0.103-0.123 $\left.\mu \mathrm{g} \mathrm{g}^{-1} \mathrm{dw}\right)$, while the Jack mackerel had only concentrations within a lower range (0.083-0.103 $\left.\mu \mathrm{g} \mathrm{g}^{-1} \mathrm{dw}\right)$. These values are within the range of concentrations (0.011-0.408 $\mu \mathrm{g} \mathrm{g}^{-1} \mathrm{dw}$ ) of inorganic As in fish reported in literature (Brooke and Evans 1981; Branch et al., 1994; López et al., 1994; Muñoz et al., 2000).

The concentrations of inorganic As found in all five species in this study were less than $10 \%$ of the total As concentrations in either fresh or cooked products, which in agreement with values reported for fresh and processed seafood products (Muñoz et al., 2000). In addition, statistical analysis indicated that specifically in common mussel and black cusk-eel, significant reductions $(\mathrm{p}<0.05)$ in the concentrations of inorganic As occurred during cooking (Table 3). The difference in the concentrations of inorganic As in the clam samples before and after cooking was not statistically significant. Although statistically significant differences in content of inorganic As were observed in Magellan mussels and Jack mackerel, the changes showed no clear tendency. Devesa et al. (2001) concluded that the effect of cooking on concentration of inorganic arsenic varied according to the type of seafood examined. In the present study, the changes in concentration of inorganic As determined in the seafood samples following cooking were small, which indicated that inorganic arsenic is strongly bound to the seafood tissues in both the fresh and cooked forms.

\section{Cadmium content in fresh and cooked seafood samples}

The concentrations of cadmium in the five species studied are given in Table 3. Among the fresh bivalves, Magellan mussel had the highest $C d$ content (2.32-4.41, $\left.\mu \mathrm{g} \mathrm{g}^{-1} \mathrm{dw}\right)$, followed by mussel (1.65-2.37 $\left.\mu \mathrm{g} \mathrm{g}^{-1} \mathrm{dw}\right)$ and clam (1.06-1.29 $\left.\mu \mathrm{g} \mathrm{g}^{-1} \mathrm{dw}\right)$. These concentrations were below values (2.2-5.8 $\left.\mu \mathrm{g} \mathrm{g}^{-1} \mathrm{dw}\right)$ reported in literature for similar species (Bruhn et al., 2002). In the two fresh fish species analysed, Cd concentrations were even lower. In the Jack mackerel Cd content (0.86-1.02 $\mu \mathrm{g}$ $\mathrm{g}^{-1} \mathrm{dw}$ ) was higher than in the black cusk-eel (0.63-0.83 $\mu \mathrm{g} \mathrm{g}^{-1} \mathrm{dw}$ ), which is within a similar range of Cd concentrations $\left(0.07-0.82 \mu \mathrm{g} \mathrm{g}^{-1} \mathrm{dw}\right)$ reported in literature for seafood products (López-Artíguez et al., 1993). In fresh maquerel from the Mediterrenean sea $\mathrm{Cd}$ contents of 0.003-0.01 $\mathrm{mg} \mathrm{kg}^{-1}$ wet weight have been reported (Falcó et al., 2006), while in Horse mackerel of the Atlantic sea, Cd contents of $0.003-0.0141 \mathrm{mg} \mathrm{kg}^{-1}$ were found (Vieira et al., 2011).

No statistically significant differences in Cd contents were observed between cooked and uncooked common mussels and clams. The absence of a reduction in Cd concentration following cooking suggested that $\mathrm{Cd}$ could be present in the tissues of these species in a different form, which remains more tightly bound. Wallace and Luoma (2003) described cadmium's subcellular compartmentalisation, in which $\mathrm{Cd}$ is bound to organelles, "enzymes", and metallothioneins. The principal mechanism for the detoxification of cellular $\mathrm{Cd}$ involves the binding of $\mathrm{Cd}$ to specific types of protein, metallothioneins, that then precipitate into insoluble inclusions known as metal rich granules (MRG) (Wallace and Luoma 2003). The Cd concentration measured after cooking presumably corresponds to the portion of the metal that is sequestered in MRGs, which, due to their large size and low solubility, remain bound to tissues even after thermal treatment. This metal would be in the form of cadmium sulphide (CdS) (Wallace and López 1997), which has low solubility $\left(\mathrm{K}_{\mathrm{ps}}=1 \cdot 10^{-28}\right)$. Thus, the principal mechanism of $\mathrm{Cd}$ detoxification within mussels and clams involves MRG sequestration, so the metal was not exuded into the cooking liquid.

Significant differences in Cd content between fresh and cooked samples were observed for Magellan mussels, black cusk-eels, and Jack mackerel, indicating that a significant portion of the cadmium found in these 
Table 3. Total As, inorganic As, Cd and Hg concentration in fresh and cooked seafoods.

Cuadro 3. Concentración de As total, As inorganic, Cd y Hg en productos del mar frescos y cocidos

\begin{tabular}{|c|c|c|c|c|}
\hline & \multicolumn{4}{|c|}{ Concentration (Mean \pm SD) } \\
\hline & Total As & Inorganic As & $\mathrm{Cd}$ & $\mathrm{Hg}$ \\
\hline & $\mu \mathrm{g} \mathrm{g}^{-1} \mathrm{dw}$ & $\mu \mathrm{g} \mathrm{g}^{-1} \mathrm{dw}$ & $\mu g g^{-1} d w$ & $\mu \mathrm{g} \mathrm{g}^{-1} \mathrm{dw}$ \\
\hline \multicolumn{5}{|l|}{ Jack mackerel } \\
\hline Baked & $1.36 \pm 0.09^{\mathrm{a}}$ & $0.12 \pm 0.01^{\mathrm{a}}$ & $0.50 \pm 0.03^{\mathrm{a}}$ & $0.14 \pm 0.04^{\mathrm{a}}$ \\
\hline Boiled & $1.33 \pm 0.05^{\mathrm{a}}$ & $0.09 \pm 0.01^{b}$ & $0.76 \pm 0.07^{\mathbf{b}}$ & $0.19 \pm 0.08^{a}$ \\
\hline Fresh & $2.06 \pm 0.45^{b}$ & $0.09 \pm 0.01^{b}$ & $0.95 \pm 0.06^{c}$ & $0.17 \pm 0.07^{a}$ \\
\hline \multicolumn{5}{|l|}{ Black cusk eel } \\
\hline Baked & $2.87 \pm 1.30^{\mathrm{a}}$ & $0.08 \pm 0.01^{\mathrm{a}}$ & $0.32 \pm 0.04^{\mathrm{a}}$ & $0.38 \pm 0.06^{a}$ \\
\hline Boiled & $3.00 \pm 1.51^{\mathrm{a}}$ & $0.07 \pm 0.01^{\mathrm{a}}$ & $0.39 \pm 0.12^{\mathrm{a}}$ & $0.31 \pm 0.06^{\mathrm{a}}$ \\
\hline Fresh & $4.09 \pm 0.34^{\mathrm{a}}$ & $0.11 \pm 0.01^{b}$ & $0.75 \pm 0.08^{b}$ & $0.29 \pm 0.08^{a}$ \\
\hline
\end{tabular}

Clam

\begin{tabular}{|c|c|c|c|c|}
\hline Baked & $8.57 \pm 0.89^{a}$ & $0.22 \pm 0.03^{\mathrm{a}}$ & $1.23 \pm 0.25^{\mathrm{a}}$ & $0.16 \pm 0.05^{\mathrm{a}}$ \\
\hline Boiled & $9.53 \pm 0.46^{\mathrm{ab}}$ & $0.19 \pm 0.06^{\mathrm{a}}$ & $1.07 \pm 0.18^{\mathrm{a}}$ & $0.13 \pm 0.03^{a}$ \\
\hline Fresh & $11.04 \pm 1.60^{b}$ & $0.15 \pm 0.03^{a}$ & $1.22 \pm 0.10^{a}$ & $0.13 \pm 0.06^{a}$ \\
\hline
\end{tabular}

Mussel

\begin{tabular}{|c|c|c|c|c|}
\hline Baked & $9.13 \pm 0.74^{a}$ & $0.09 \pm 0.05^{a}$ & $2.25 \pm 0.12^{\mathrm{a}}$ & $0.08 \pm 0.03^{a}$ \\
\hline Boiled & $8.17 \pm 0.50^{a}$ & $0.15 \pm 0.08^{\mathrm{ab}}$ & $1.94 \pm 0.31^{\mathrm{a}}$ & $0.15 \pm 0.03^{a}$ \\
\hline Fresh & $7.48 \pm 1.72^{\mathrm{a}}$ & $0.20 \pm 0.02^{b}$ & $1.94 \pm 0.30^{\mathrm{a}}$ & $0.16 \pm 0.09^{a}$ \\
\hline
\end{tabular}

Magellan mussel

$\begin{array}{lllll}\text { Baked } & 10.67 \pm 0.47^{\mathrm{a}} & 0.13 \pm 0.02^{\mathrm{a}} & 1.50 \pm 0.11^{\mathrm{a}} & 0.06 \pm 0.02^{\mathrm{a}} \\ \text { Boiled } & 10.73 \pm 0.67^{\mathrm{a}} & 0.16 \pm 0.01^{\mathrm{b}} & 1.75 \pm 0.83^{\mathrm{a}} & 0.08 \pm 0.02^{\mathrm{a}} \\ \text { Fresh } & 14.26 \pm 0.53^{\mathrm{b}} & 0.14 \pm 0.02^{\mathrm{ab}} & 3.51 \pm 0.77^{\mathrm{b}} & 0.09 \pm 0.02^{\mathrm{a}}\end{array}$

Different letters in the same column indicate significant difference, $\alpha=0.05$.

species is bound to metallothionein. The binding of Cd to sulfhydryl-rich proteins, such as metallothioneins, is well documented (Kido et al., 1991). Because metallothioneins are highly soluble thermo-resistant proteins, the reduction in Cd content could occur, when metallothionein is exuded into the cooking liquid. The fraction of Cd present in the samples after cooking corresponds to the sequestered Cd in the MRGs.

\section{Mercury content in fresh and cooked seafood samples}

The mercury concentrations present in the five species examined are summarised in Table 3. Among the bivalves, $\mathrm{Hg}$ concentrations was highest in common mussels (0.042-0.280 $\mu \mathrm{g} \mathrm{g}^{-1} \mathrm{dw}$ ), followed by clams (0.079-0.205 $\mathrm{\mu g} \mathrm{g}^{-1} \mathrm{dw}$ ) and Magellan mussels (0.075- 
$0.117 \mu \mathrm{g}^{-1} \mathrm{dw}$ ). The black cusk-eel had the highest $\mathrm{Hg}$ content among all the seafoods analysed in this study $\left(0.223-0.396 \mu \mathrm{g} \mathrm{g}^{-1} \mathrm{dw}\right)$. Jack mackerel presented concentrations in a range similar to that obtained for the bivalves (0.108-0.250 $\mu \mathrm{g} \mathrm{g}^{-1} \mathrm{dw}$ ). However, the levels of mercury concentrations of all samples were below the maximum values for fresh or frozen fish products as stipulated by Chilean law (González, 2006), i.e. $0.5 \mu \mathrm{g}$ $\mathrm{g}^{-1}$ (wet basis) or $2.0 \mu \mathrm{g} \mathrm{g}^{-1} \mathrm{dw}$, assuming a moisture content of $70 \%(\mathrm{w} / \mathrm{w})$.

The levels of mercury in a given species depend on the organisms'surroundings. In fresh maquerel from the Mediterranean sea Hg contents of 0.06-0.015 $\mathrm{mg} / \mathrm{kg}$ have been reported (Falcó et al.,2006), while in Horse mackerel of the Atlantic sea, $\mathrm{Hg}$ contents of $0.038-0.3371 \mathrm{mg} / \mathrm{kg}$ were found (Vieira et al., 2011). Subjecting seafood samples to thermal treatments did not significantly reduce their mercury contents (Table 3). This implied that the mercury is tightly bound to the fish and shellfish tissues and that heating was insufficient to promote solubilisation. The particular form in which mercury is found in seafood is methyl mercury (Amlund et al., 2007). Harris et al. (2003) inferred that methyl mercury in fish was likely to be bound to the cysteine residues of peptides (e.g., glutathione) or proteins. This suggested that methyl mercury efficiently accumulates in the muscles, where it is probably found as a complex compound with protein that is not easily disrupted by thermal processes. Consequently the presence of mercury in foods is particularly unsafe.

\section{CONCLUSIONS}

The cooking processes significantly reduced the $\mathrm{Cd}$ and As concentrations of the fish samples analysed. However, these reductions were small compared to the original concentrations, so that the cooking process did not significantly reduce the toxicity with respect to the heavy metals. In clams and common mussel significant reduction of $\mathrm{Cd}$ and As was not observed. Mercury content showed no significant changes in any of the cooking processes, probably due to the formation of a complex compound between methyl mercury and the sea food protein. The presence of mercury in seafood is therefore particularly unsafe. Heavy metals in foods are a risk factor for long-term effect on the human body, since it tends to accumulate in human tissues.

\section{ACKNOWLEDGEMENTS}

The authors acknowledge financial support from Dirección de Investigación, Universidad del Bío-Bío (DIUBB Research Grant 075121 3/R), Dirección de Investigación y Desarrollo, Universidad Austral de Chile (DID-S-2007-35) and the CyTED Program 105PI0272.

\section{CONFLICT OF INTEREST}

The authors have no conflict of interest to declare.

\section{REFERENCES}

ACKLEY, K.L., B'HYMER, C., SUTTON, K.L., CARUSO, J.A. 1999. Speciation of arsenic in fish tissue using microwaveassisted extraction followed by HPLC-ICP-MS. Journal of Analytical Atomic Spectrometry 14: 845-850.

AMLUND, H., LUNDEBYE, A.K. BERNTSSEN, M.H.G. 2007. Accumulation and elimination of methyl mercury in Atlantic cod (Gadus morhua L.) following dietary exposure. Aquatic Toxicology 83: 323-330.

ATSDR (Agency for Toxic Substances and Disease Registry). 1999. Toxicological Profile for Cadmium. Public Health Human Services, Centers for Diseases Control, Atlanta: U.S. Department of Health and Human Services.

ATSDR (Agency for Toxic Substances and Disease Registry). 2003.Toxicological Profile for Mercury. Public Health Human Services, Centers for Diseases Control, Atlanta: U.S. Department of Health and Human Services.

ATTAR, K.M., EL-FAER, M.Z., RAWDAH, T.N. TAWABINI, B. 1992. Levels of Arsenic in Fish from the Arabian Gulf. Marine Pollution Bulletin 24: 94-97.

BRANCH, S., EBDON, L., ONEILL, P. 1994. Determination of Arsenic Species in Fish by Directly Coupled High Performance Liquid Chromatography Inductively Coupled Plasma Mass Spectrometry. Journal of Analytical Atomic Spectrometry 9: 33-37.

BROOKE, P.J. EVANS, W.H. 1981.Determination of total inorganic arsenic in fish, shellfish and fish products. Analyst 106: 514-520.

BRUHN, C., CAMPOS, V., DÍAZ, V., CID, H. NÓBREGA., A. 2002. Determination of $\mathrm{Cd}$ in mussels and not-fat milk powder by flow injection-flame atomic absorption spectrophotometry (FI-FAAS) with on-line extraction by a chelating resin. Boletín de la Sociedad Chilena de Química 47: 123-135.

CARRASCO, L., BENEJAM, L., BENITO, J., BAYONA, J.M. DÍEZ, S. 2011. Methyl mercury levels and bioaccumulation in the aquatic food web of a highly mercury-contaminated reservoir. Environmental International 37: 1213-1218.

CHAHID, A., HILALI, M., BENLHACHIMI, A., BOUZID, T. 2014. Contents of cadmium, mercury and lead in fish from the Atlantic sea (Morocco) determined by atomic absorption spectrometry. Food Chemistry 147: 357-360.

DEVESA, V., MACHO, M.L., JALÓN, M., URIETA, I., MUÑOZ, O., SUÑER, M. A., LÓPEZ, F., VÉLEZ, D., MONTORO, R. 2001. Arsenic in cooked seafood products: study on the effect 
of cooking on total and inorganic arsenic contents. Journal of Agricultural and Food Chemistry 49: 4132-4140.

EKINO, S., NINOMIYA, T., SUSA, M. 2004. Letters; In Their Brevia "The Chemical Form of Mercury in Fish" Science 303:763-764.

FALCÓ, G., LLOBET, J.M., BOCIO, A., DOMINGO, J.L. 2006. Daily intake of arsenic, cadmium, mercury and lead by consumption of edible marine species. Journal of Agricultural and Food Chemistry 54: 6106-6112.

GONZÁLEZ, C. 2006. Nuevo Reglamento Sanitario de los Alimentos. Ediciones Publiley, Santiago, Chile, pp. 63-69.

HARRIS, H.H., PICKERING, I.J., GEORGE, G.N. 2003. The Chemical Form of Mercury in Fish, Science 301: 1203.

HORIGUCHI, H., OGUMA, E., KAYAMA, F. 2006. Cadmium and cisplatin damage erythropoietin-producing proximal renal tubular cells. Archives of Toxicology 80: 680-686.

JIN, L., ZHANG, L., LI, Z-W, LIU, J-M, YE, R., REN, R. 2013. Placental concentrations of mercury, lead, cadmium and arsenic and the risk of neural tube defects in a Chinese population. Reproductive Toxicology 35: 25-31.

KIDO, T., SHAIKH, Z.A., KITO, H., HONDA, R., NOGAWA, K. 1991. Dose response relationship between urinary cadmium and metallothionein in a Japanese population environmentally exposed to cadmium. Toxicology 65: 325-332.

LARSEN, E.H., PRITZL, G., HANSEN, S.H. 1993. Arsenic Speciation in Seafood Samples with Emphasis on Minor Constituents An Investigation Using High Performance Liquid Chromatography with Detection by Inductively Coupled Plasma Mass Spectrometry. Journal of Analytical Atomic Spectrometry 8: 1075-1084.

LEAH, R.T., EVANS, S.J., JOHNSON, M.S. 1992. Arsenic in plaice (Pleuronectes platessa) and whiting (Merlangius merlangus) from the north east Irish Sea. Marine Pollution Bulletin 24: 544-549.

LLOBET, J.M., FALCÓ, G., CASAS, C., TEIXIDÓ, A., DOMINGO, J.L. 2003. Concentrations of arsenic, cadmium, mercury, and lead in common foods and estimated daily intake by children, adolescents, adults, and seniors of Catalonia, Spain. Journal of Agricultural and Food Chemistry 51: 838-842.

LÓPEZ, J.C., REIJA, C., MONTORO, R., CERVERA, M.L., DE LAGUARDIA, M. 1994. Determination of Inorganic Arsenic in Seafood Products by Microwave Assisted Distillation and Atomic Absorption Spectrometry. Journal of Analytical Atomic Spectrometry 9: 651-656.

LÓPEZ-ARTÍGUES, M., SORIA, M.L., CAMEÁN, A., REPETTO, M. 1993. Cadmium in the diet of the local population of Seville (Spain). Bulletin of Environmental Contamination and Toxicology 50: 417-424.
LOW, K.S., LEE, C.K. 1992. Arsenic contents in some Malaysian vegetables. Pertanika Journal of Tropical Agricultural Science 15: 171-173.

MARTORELL, I., PERELLÓ, G., MARTÍ-CID, R., LLOBET, J.M., CASTELL, V., DOMINGO, J.L. 2011. Human exposure to arsenic, cadmium, mercury and lead from foods in Catalonia, Spain: Temporal trend. Biological Trace Element Research 142: 309-322.

MANAHAN, S.E. 2003. Toxicological chemistry and biochemistry, Chapter 10, Toxic elements, Lewis Publishers, CRC Press LLC, Boca Raton.

MUÑOZ,O., VÉLEZ, D., MONTORO, R. 1999a. Optimization of the solubilization, extraction and determination of inorganic arsenic in seafood products by acid digestion, solvent extraction and hydride generation atomic absorption spectrometry. Analyst 124: 601-607.

MUÑOZ, O., VÉLEZ, D., CERVERA, M.L., MONTORO, R. 1999b. Rapid and quantitative release, separation and determination of inorganic arsenic [As (III) + As (V)] in seafood products by microwave-assisted distillation and hydride generation atomic absorption spectrometry. Journal of Analytical Atomic Spectrometry 14: 1607-1613.

MUÑOZ, O., DEVESA, V., SUÑER, M.A., VÉLEZ, D., MONTORO, R., URIETA, I., MACHO, M.L., JALÓN, M. 2000. Total and inorganic arsenic in fresh and processed fish products. Journal of Agricultural and Food Chemistry 48: 43694376.

MUÑOZ, O., BASTÍAS, J.M., ARAYA, M., MORALES, A., ORELLANA, C., REBOLLEDO, R., VELEZ, D. 2005. Estimation of the dietary intake of cadmium, lead, mercury and arsenic by the population of Santiago (Chile) using a Total Diet Study. Food and Chemical Toxicology 43: 16471655.

OLMEDO, P., PLA, A., HERNÁNDEZ, A.F., BARBIER, F., AYOUNI, L., GIL, F. 2013. Determination of toxic elements (mercury, cadmium, lead, tin and arsenic) in fish and shellfish samples. Risk assessment for the concumers. Environmental International 59: 63-72.

SCHUHMACHER, M., DOMINGO, L.J. 1996.Concentrations of Selected Elements in Oysters (Crassostrea angulata) from the Spanish Coast. Bulletin of Environmental Contamination and Toxicology 56: 106-113.

SHIOMI, K. 1994. Arsenic in marine organisms: Chemical forms and toxicological aspects. Arsenic in the Environment. In: Nriagu, J.O. (Ed.), Arsenic in the Environment, Part II: Human Health and Ecosystem Effects John Wiley \& Sons Inc., New York, pp. 261-282.

ŠLEJKOVEC, Z., BYRNE, A.R., SMODIŠ, B., ROSSBACH, M. 1996. Preliminary studies on arsenic species in some environmental samples. Fresenius' Journal of Analytical Chemistry 354: 592-595. 
VÉLEZ, D., IBAÑÉZ, N., MONTORO, R. 1997. Determination of Arsenobetaine in Manufactured Seafood Products by Liquid Chromatography, Microwave assisted Oxidation and Hydride Generation Atomic Absorption Spectrometry. Journal of Analytical Atomic Spectrometry 12: 9196.

VIEIRA, C., MORAIS, S., RAMOS, S., DELERUE-MATOS, C., OLIVEIRA, M.B.P.P. 2011. Mercury, cadmium, lead and arsenic levels in three pelagic fish species from the Atlantic Ocean: Intra- and inter-specific variability and human health risks for consumption. Food and Chemical Toxicology 49: 923-932.
VLIEG, P., LEE, J., GRACE, N. 1991. Elemental Concentration of Marine and Freshwater Finfish, and Shellfish from New Zealand Waters. Journal of Food Composition and Analysis 4: 136-147.

WALLACE, W., LUOMA, S. 2003. Subcellular compartmentalization of $\mathrm{Cd}$ and $\mathrm{Zn}$ in two bivalves. II. Significance of trophically available metal (TAM). Marine Ecology Progress Series 257: 125-137.

WALLACE, W., LOPEZ, G.R. 1997.Bioavailability of biologically sequestered cadmium and the implications of metal detoxification, Marine Ecology Progress Series 147: 149-157. 
